\title{
Supra-Situational Approach as Basis for Creative Professional Thinking
}

\author{
Mergalias M. Kashapov* \\ Yaroslavl State University named after P.G. Demidov \\ 9 Matrosov Str., Yaroslavl, 150057, Russia
}

Received 11.09.2014, received in revised form 20.10.2014, accepted 19.11.2014

\begin{abstract}
Problem of diagnosis and formation of creative professional thinking is one of the fundamental problems in educational psychology. Creativity plays an important role in professional activities, so a low level of development of design expertise does not allow to produce effective strategies and methods of teaching activities, leading to the selection of incorrect, non-constructive ways of behavior is not conducive to the realization of its activities and, as a consequence, leads to stagnation professional educator.

The article presents a study on the solution of the important psychological and pedagogical issuesidentify, describe, diagnosis and as a basis for the formation of suprasituational creative professional thinking. The article proves that the teaching activities suprasituational mindset teacher acts leading, core competencies, without which the implementation of the educational process at a high level.
\end{abstract}

Keywords: suprasituational mindset, professional creative thinking, pedagogical activity.

The work was supported by the RGNF grant (project No. 13-06-00589a).

Research area: pedagogy, psychology.

If we turn to the scientific legacy of S.L. Rubinstein, A.V. Brushlinskii, we will see that the range of issues, wherein they worked, were eventually subordinated to the theoretical and methodological foundation and methodological support of the study of the subject's thinking as a process. Psychology of the subject was studied by S.L. Rubinstein [Rubinstein] and in completed forms it was examined in the works of A.V. Brushlinskii [Brushlinskii], who identified the following poles in the subject: cultural and activity poles. Integrity, unity, integral characteristic are important properties of the subject, the basis for the system of all its mental qualities, which are often quite contradictory and difficult to reconcile. Thinking process begins with an analysis of the problem situation. As a result of its analysis a task (a problem) in the true sense of the word emerges. Emergence of the problem means that we managed at least to predivide given (known) and unknown (desired). On the basis of connection and relationships between the known and the unknown, it is possible, according to A.V. Brushlinskii, to seek and find something new, which before was hidden, unknown. Established by A.V. Brushlinskii tradition of studying thinking as a prediction of the unknown, as originally creative process

(C) Siberian Federal University. All rights reserved

* Corresponding author E-mail address: smk007@bk.ru 
of generating subjective and objective new knowledge, has allowed us see supra-situational thinking as the basic quality of the creative professional thinking, that is characterized by the ability to rise above the level of the immediate requirements of the situation; detect suprasituational problematic; set goals, which are excessive in terms of the original problem to be solved [Brushlinskii].

The idea of supra-situational approach as the ability to overcome limitations in the choice situation, to transform the alternatives available was revealed in the writings of philosophers (Kant et al.) and psychologists. V.A. Petrovskii in his studies considered supra-situational character of actions; supra-situational manifestations in the art were studied by D.B. Bogoiavlenskaia; A.G. Asmolov applied this idea to the study of personality; V.T. Kudriavtsev concerned mental activity of children; professional thinking of the teachers was researched by M.M. Kashapov, T.G. Kiseliova, Ie.V. Kotochigova, Iu.V. Poshekhonova, O.A. Shliapnikova,N.V.Dudyreva, Ie.V. Shubina and others). And in each of these cases, the concept of supra-situational has its own peculiarities, and sometimes a different meaning. Situational - supra-situational thinking of a teacher makes a difference in the structure of the psychological system of pedagogical activity (T.G. Kiseliova). Supra-situational level of the problem detection gives a certain (new) sense of professional activity. Optimality, efficiency and adequacy of a certain level can only be determined via taking into account the situation where they can be applied (Iu.N. Zhikhareva). Since pedagogical thinking determines the whole character of the professional activity, researchers M.M. Kashapov, Iu.S. Kolikova, A.V. Leibina, T.V. Ogorodova, T.V. Razina, O.N. Rakinskaia, I.V. Serafimovich, O.V. Sumarokova, S.A. Tomchuk and others consider situational- supra-situational modes as a basic characteristic of pedagogical thinking and speak only about situational-supra-situational levels of thinking in general, but not about the levels of problem detection.

There are two levels of detecting pedagogical problems: situational and supra-situational. Implementation at the supra-situational level allows detecting the contradiction that may be realized not only in the direct confrontation of people and developed from the beginning to the resolution, but against a steady, stable background of events, regardless of the specific situation in the thoughts and feelings of its members, full of emotional intensity. Implementation at the supra-situational level allows for an overall view of the events of the life, a certain (new) sense in undertaking professional activities, without losing the broader perspective and sinking into the fine details of the situation.

Differences in levels of detection pedagogical problems can be considered on four characteristics: emotional sphere, motivational sphere, intellectual sphere and personality changes.

Emotional sphere. 1. Situational level is characterized by the teacher's sense of a tense attitude towards pedagogical problem situation and the difficulty of its solution. 2. Suprasituational level is characterized by the ability to quickly change the behavior, natural reactions, efficiency of overcoming negative emotions, minor form of psychological defenses.

Motivational sphere.1 Situational motivation of a teacher: it is important to correct the interference only now, and what will happen next is not so important - situational level. 2 . The teacher perceives the problem situation as a creative task, seeks to reveal the hidden motives of a student - supra-situational level.

Intellectual sphere. 1 . The teacher finds out what causes a conflict and ways to remove or overcome it, which happens due to the influence of specific pedagogical conditions - situational 
level. 2. The ability to "go beyond" the specific situation, originality, flexibility of thinking, vision of the object from the qualitatively new standpoint; analysis of the own behavior and actions; taking into account possible consequences for the educational and training process - suprasituational level.

Personality changes. 1 . There is no systematic personal growth of a teacher, who finds it hard to overcome stereotypes - situational level. 2 . A teacher is aware of the need to change, selfimprove - supra-situational level.

A critical area of research for these problems is that if initially it was thought that the situational level is far more complex and at the same time more efficient, now it is assumed that the optimality, efficiency and value of a certain level shall be determined only taking into account the situation where they can be applied. Generalization of the results obtained in our research suggests two types of thinking that have been allocated on the basis of theoretical analysis used in detecting the levels of problems. Similar conclusions were drawn by T.G. Kiseliova, who analyzed the process of teacher's professional thinking on the basis of an empirical study of pedagogical activities, where the concept of systemogenesis invented by V.D. Shadrikov was used as a structure diagram for a psychological analysis of pedagogical activity [Shadrikov, 1982; Shadrikov, 2007]. The study results showed that all six main blocks of professional pedagogical activity are different for teachers with situational and supra-situational levels of detecting pedagogical problems.

Since pedagogical thinking is intrinsic for the main content of professional activity of a teacher, situational-supra-situational approach can be observed as a pedagogical thinking characteristic and situational-supra-situational levels of thinking can be regarded as a whole, not only when they are applied to detecting the problems. In general, such qualities as situational-supra- situational modes are generic characteristics of pedagogical thinking. Manifestation of specific characteristics is supplemented mainly by the features in the situational context of pedagogical activity.

Therefore creative professional thinking process is seen as realizing at two levels: situational and supra-situational. Dominant situational and dominant supra-situational levels are the poles of a continuum of levels of thinking. Situational thinking is characterized by the influence of the priority of life circumstances, connected with short-term orientation of the professional individual. In the process of situational thinking realization a problem is not singled out as the original contradiction. Situational thinking is defined by the features of the situation and is limited to its basic features (temporal, organizational, activity ones). Such professionals have random introspection and selfhelp, and the emphasis in addressing professional problem situation shifts to search for external assistance. Situational level is conditioned by the emotional attitude to the situation to be solved and to its participants. There is tendency to address the problem directly and immediately without its preliminary analysis, to reconstruct professional activity, i.e. there is an inclination to change the situation without changing, self-change in this situation. The main aim of a professional, who thinks and acts at this level, is focused on removal of the visible problem without taking into account its etiology.

When thinking shifts from the situational to supra-situational level, a number of requests for external help decreases, self-help methods begin to prevail. Professionals with supra-situational thinking level have a high level of self-analysis, activation of their own potential opportunities and experience, increasing critical approach to their actions and self-efficacy. Supra-situational level of thinking is characterized by going of the subject 
in their thinking beyond this immediate situation. In addressing the problem a professional person actualizes not only practical, but also theoretical psychological knowledge. Every act of situations' outcome is characterized by orientation to selfdevelopment and creativity. Specialists using supra-situational level are more successful in carrying out their professional duties.

The ability to analyze a problem situation thoroughly and to make balanced, reasoned value judgments allow supra-situationally thinking professionals to perform their activities more efficiently. A specialist, who is able to think supra-situationally, analyzes the characteristics of the problem situation and begins to realize their own professional actions, which helps him to accept and implement constructive solution to deal with the arising difficulties.

The ability to distinguish supra-situational problem mode within the process of problem solving not only fosters thinking activity awakening, but also has a great impact on the personal development of a professional. And this, in turn, leads to the formation of personal attitudes, beliefs, thus helping to improve their professional activities. Personal level is characterized by a set of the professional's attitudes to a problematic situation as a whole, to themselves and their activities. That is why the supra-situational level of the problem resolution for the professional is associated with creativity self-actualization. However, if the professional just stops at one level, then a holistic embodiment of creative performance of the activity, as well as prospects for its further improvement, are lost.

Men are able to "remove" themselves from the situation, to look at themselves from outside, and thus - to cease to be what it they were before (M.K. Mamardashvili). In order to lift above the tragic situation, to be able to look at themselves from outside and to find funny points in this situation, one needs to have an extraordinary fortitude. Peace of mind in a difficult situation is provided as follows: people are "alienated" from themselves, look at themselves from outside, and this, at first purely intellectual operation, shifts the "emotional resultant" in a positive way. As a consequence, the disease can occur as a result of the wrong thoughts, wrong acts. In this case, the balance between the good and the bad leaned toward the bad. Therefore, we assume as fair a statement of G.W.F. Hegel that the wrong thinking leads to headaches.

Intellectual and enterprising men tend to expandcognitiveactivitiesoutsidetherequiredtask, to raise problems independently, to establish new patterns. A creative desire arises unconsciously, but a way to implement the desire is determined consciously. Rational action is regulated on the basis of reflection, which interprets suprasituational mode in human activity. In the process of supra-situational problem solution activation, it is possible to consider different points of view on the problem to be solved, to play out various consequences of the proposed solutions. Thanks to the supra-situational approach a person can not only improve the work performed, but also selfimprove as a subject of activity.

Situational - supra-situational thinking is present not only in the professional pedagogical thinking, but also at the clinical stage of the medical profession teaching (Kashapov, M.M., Skvortsova, Iu.V., 2007). In one of the studies the researchers (Kashapov, M.M., Alekseeva, S.V., 2006) found that at the situational level doctor solves diagnostic task using available knowledge and experience without departing from the scope of the specific situation. It is at this level, along with other styles of thinking, a reproductive style appears as one of the sublevels, where the doctor situationally uses patterns of action at his professional disposal. Intellectual activity of the doctor is aimed at knowing and changing specific medical situation. 
At supra-situational level the doctor's attention is drawn not only to solving a particular problem solution in the context of achieving the intended result, but also a reflection of the thinking process itself. The outcome of this reflection may be a deeper awareness of the doctors of their own personalities. At this level, the doctor might go beyond the specific diagnostic task, realize and further take into account their individual characteristics that affect the process of solving clinical problems. In addition, professional thinking at this level will allow the doctor to solve the problems of their own professional growth through personal changes.

Both levels are important for professional activity of a doctor. However, the level of development of each of them is not often the same. Therefore, one of the objectives of vocational training in medical school should be the task of forming professional thinking, which consists in a harmonious combination of both levels. This combination will help young professionals to form a flexible, logical, independent, reflective thinking, and also such important personal characteristics as the ability to take responsibility for the results of professional tasks, the ability to master selfknowledge and self-development.

Supra-situational thinking allows nurses to be creative and apply highly professional approach in their professional activities (I.N. Saidova, I.V. Serafimovich). In addition, it was found that supra-situational thinking of high school students can not only help them to successfully resolve conflict and stressful situations, but also to overcome personal crises, to acquire the ability to holistically see problematic situations and perform the selection of successful conditions of family welfare (I.V. Serafimovich, Ie.D. Morugina, S.A. Granovskii), military service (M.V. Bashkin, V.V. Pekhterev), the research activities of students, university professors (A.L. Mazaletskaia,
Iu.S. Medvedeva, T.V. Ogorodova), musical performance (S.A. Tomchuk, S.V. Tsymzina).

In our study, carried out jointly with T.V. Razina (2002), we identified the regularities and interactions of the thinking level and patterns of reflection. In particular supra-situational level of thinking is characterized by relatively uniform development of all allocated by us reflection constituents, though in absolute terms they may be significantly lower than the individual performance of reflection at the situational level, while the supra-situational level is characterized by heterogeneous values of reflection indicators. We found a complex and ambiguous relationship between the thinking level and the reflection level, thus proving that a high level of reflection is not yet a guarantee of a high level of pedagogical thinking.

In a study conducted in conjunction with Iu.S. Kolikova applying of the rank-correlation coefficient of C. Spearman made it possible to establish that there is a relationship between the supra-situational style of pedagogical thinking and such types of responses to conflict as "Aggression", "Leaving" and "Solution". It was found that the higher the supra-situational thinking style, the lower the response type "Aggression". Type of response "Aggression" implies the desire to defend their views, with open expression of dissatisfaction, concern, anger, and experience in dealing with conflict situations. Implementation of the supra-situational style of thinking implies the willingness to go beyond the conflict (problem) situation, while setting cognitive tasks. A teacher, who has a high style of the supra-situational thinking, is able to more objectively analyze the conflict situation, to see the solution of the conflict situation, analyze their actions and, hence, minimize the use of such type of response as "Aggression", which does not involve an objective assessment of the conflict situation. By the way, the high style of the supra- 
situational thinking is characterized by low index of to such type of conflict response as "Leaving". Implementation of this type of response to conflict suggests that the teacher in the (problem) conflict relies more on the other, is afraid to take responsibility for making the decision, pays no attention to the own past experience. The supra-situational thinking style implies not only the objective situation assessment, but also involvement of the past experience in decisionmaking process. A teacher, who has the high style of the supra-situational thinking can both be objective in a conflict situation and update and implement their experience that can help in solving the conflict, minimizing the use of such type of optimal response to the conflict as "Leaving", which is characterized by a disregard for past experience. Implementation of the optimal type of reaction "Solution" involves rational decision making, taking responsibility, acceptance of other points of view on the current conflict (problem) situation. A teacher, who has the high supra-situational thinking, uses such type of optimal response to the conflict as the "Solution" as the best approach to the problem situation, as it involves taking responsibility for making the decision and taking into account all points of view on the conflict situation.

Rank correlation coefficient of C. Spearman when applied to groups with different experience revealed that:

- Teachers with school experience under 5 years demonstrate a relationship between the supra-situational style of pedagogical thinking and the type of optimal response to the conflict "Solution", i.e. the higher supra-situational style of thinking, the higher the level of such type of optimal response as the "Solution". This is due to the fact that young professionals at the start of pedagogical activity have sufficient professional knowledge, as they had just recently graduated from high school. They found easy coping with the assessment situation; they can find a new perception of themselves and their environment; they are prone to selfchange.

- A group of teachers with school experience of $6-10$ years have a relationship between the supra-situational style of pedagogical thinking and the type of response "Leaving", i.e. the higher supra-situational style of thinking, the lower the level of such type of response as "Leaving". This is due to the fact that these teachers develop an arsenal of methods and techniques of teaching. The number of destructive decreases thanks to the falling necessity of the teacher to assert themselves in their own and students' eyes, a year-on-year growing professional significance of the teacher.

- A group of teachers with school experience of 11 - 20 years have a relationship between the supra-situational style of pedagogical thinking and the type of response "Solution", i.e. the higher supra-situational style of thinking, the lower the level of such type of response as "Solution". This is due to the fact that the teachers of this group are more interested in the students, are able to establish a constructive relationship with them. They are less likely than younger teachers to use requirements, threats and punishment.

- Agroup of teachers with school experience of $21-25$ years have a relationship between the supra-situational style of pedagogical thinking and the type of response "Solution", i.e. the higher suprasituational style of thinking, the lower the level of such type of response as "Solution". 
This relationship is characterized by the fact that the teachers of this category have a balanced combination of high-level professional and personal development, which is manifested in the use of indirect methods of influence on students.

- A group of teachers with school experience of over 25 years have a relationship between the supra-situational style of pedagogical thinking and the type of response "Solution", i.e. the higher supra-situational style of thinking, the lower the level of such type of response as "Solution". This relationship might be caused by the fact that these teachers have the richest experience, more flexible behavior and thinking.

One-way analysis of variance revealed that there exists a relationship between teaching experience and such type of response as "Aggression", i.e. the more teaching experience is, the lower is the level of such type of response as "Aggression". This may be due to the fact that teachers, who have worked for a long time, posses extensive teaching experience and have more knowledge about what strategies should be used in problem solving. We can assume that this relationship is stipulated by the age criteria, as the worldly-wise teacher becomes more tolerant of provocations and conflicts.

Analysis of the significance of differences (by the U-Mann-Whitney test) showed that there are significant differences between the groups of teachers with experience of under 5 years and of $11-20$ years of work in the school regarding the type of response "Aggression" ( $p<0.05)$. As for the type of response to the conflict "Leaving" there are significant differences between the groups of teachers with experience of over 5 years, with the experience of $21-25$ years $(p<0.05)$ and with the experience of 25 years of work in the school $(p<0.01)$. This may indicate the fact that teachers with little work experience often use disciplinary methods of influence, trying not to succumb to provocations students; they often ignore the problem situation, whereas teachers with more experience in the school work try to minimize disciplinary methods, and strive to engage in constructive dialogue with the students.

The correlation between the supra-situational style of pedagogical thinking and the optimal type of response to the conflict was detected as such: the higher the style of supra-situational teacher's thinking, the higher the optimal type of response to conflict.

There was established the correlation between the supra-situational style of thinking and pedagogical experience, i.e. supra-situational style of thinking is most pronounced in the group of teachers, who have experience of $6-10$ years of work in the school. In the process of improving teachers' choice of methods and techniques of training there is an increase in their professional status and recognition. The lowest level of the supra-situational thinking style was expressed in the group of teachers with experience of over 25 years in school. This is linked to the fact that this category of teachers manifests a system of deeprooted stereotypes, well-established rules of professional activities, demotivation to teaching, which is a serious obstacle to their further professionalization.

There was described the relationship between the optimal type of response of the teacher and teaching experience, i.e. teachers, having worked from 6 to 10 years in the school, expressed most vividly the optimal type of response to the conflict. Perhaps this is interlinked with the fact that these teachers have already formed a set of methods to work with students and accumulated certain experience. The number of conflicts associated with the need to assert themselves in their own and students' eyes reduces. The lowest level of the optimal response to the conflict was 
shown by teachers with experience of over 25 years in school on account of that this category of teachers is characterized by intolerance to new and violations in constructive relationships with students.

Generalization of the empirical data allowed us to identify the main characteristics of the creative professional thinking directions (see Table 1, 2).

Consequently, the supra-situational type of professional thinking regarding tits psychological mechanisms is a means of personal development.

Any supra-situational thinking can be creative, but not every creative thinking can be supra-situational. After talking with a person, it is possible to determine at what level of development they stopped. Many people stop at the achieved success in realization high social values-, thereby reducing the need for self-development. Supra- situational thinking can make the condition of internal self-regulation and self-improvement activities. Mastering supra-situational thinking means, above all, the ability to recognize and manage the cause-and-effect relationships.

Supra-situational thinking is characterized by a set of key intellectual competencies needed to transform people themselves as a subject of activity. Situational thinking possesses a set of competencies that are relevant to the successful implementation of the activities, and if necessary, to its transformation. An operational component of situational thinking involves understanding the main, basic characteristics of the situation to be solved. Totality of generalized signs in the situation to be known constitutes the structure of situational thinking. This structure is both static and dynamic. A static component includes the universal sustainable elements of thinking

Table 1. Main characteristics of the creative professional thinking directions

\begin{tabular}{|l|l|l|}
\hline Direction & \multicolumn{1}{|c|}{ Situational thinking } & \multicolumn{1}{c|}{ Supra-situational thinking } \\
\hline Contents of thinking & External locus of control & Search of a problem in the situation \\
\hline Efficiency & $\begin{array}{l}\text { Search of a problem outside, out } \\
\text { of boundaries (temporal, spatial, } \\
\text { organizational) of the situation }\end{array}$ \\
\hline Strategy of professional activities & $\begin{array}{l}\text { Transformation of the situation, } \\
\text { leading to a change in professional } \\
\text { activities }\end{array}$ & $\begin{array}{l}\text { Activity transformation, leading } \\
\text { to the development of oneself as a } \\
\text { subject }\end{array}$ \\
\hline
\end{tabular}

Table 2. Psychological characteristics of professional thinking (PT)

\begin{tabular}{|l|l|l|l|l|}
\hline \multicolumn{1}{|c|}{ PT type } & \multicolumn{1}{|c|}{ PT structure } & PT level & PT determination & \multicolumn{1}{c|}{ PT functions } \\
\hline Situational PT & PT microstructure & $\begin{array}{l}\text { Situational level of } \\
\text { problem detection }\end{array}$ & $\begin{array}{l}\text { A professional } \\
\text { works according to } \\
\text { the given situation }\end{array}$ & Situation awareness \\
\hline Supra-situational PT & PT macrostructure & $\begin{array}{l}\text { Supra-situational } \\
\text { problem detection }\end{array}$ & $\begin{array}{l}\text { A professional } \\
\text { works according to } \\
\text { an idea }\end{array}$ & $\begin{array}{l}\text { Situation } \\
\text { transformation }\end{array}$ \\
\hline
\end{tabular}


(mechanisms, patterns, stages). These elements are repeated in any act of supra-situational thinking manifestation. Recognition and registration of a dynamic component as a system of the situation variable characteristics (organizational, temporal, spatial) helps the subject to understand where they are, at what level of professional and personal development. If the subject believes he/ she is in a destructive conflict, their behavior will follow and be guided by the established image of this situation. Their behavior should be designed to the image. Static and dynamic components of situational thinking interact differently with components of supra-situational thinking. Thus, the macro-structure is shown in supra-situational problem mode as cognitive education, which is characterized by: going beyond the limits of the situation; incorporation of a large number of interrelationships between the situation to be known and the situation to be solved (transformed); allocation of significant relationships; extension of the temporal and spatial knowledge; restructuring or completing the knowledge.

\section{References}

1. Brushlinskii A.V. Subject: thinking, learning, imagination. M., Publishing House "Institute of Applied Psychology"; Voronezh: NPO “Modek”, 1996, 392 p.

2. Kashapov M.M. Psychology of professional's creative thinking. Monograph. M.: PER SE, 2006, $688 \mathrm{p}$.

3. Kashapov M.M. (2012). Metacognitive approach to understanding conflict competence. Metacognitive bases of conflict competence. Scientific ed. by prof. M.M. Kashapov. Yaroslavl, Yaroslavl State University named after P.G. Demidov. Pp. 13-104.

4. Kashapov M.M. Acmeology: tutorial. Yaroslavl, Yaroslavl State University named after P.G. Demidov, 2011, 112 p.

5. Kashapov M.M. Cognitive and metacognitive understanding of the structural and dynamic characteristics of professional thinking. Professional's creative activities in the context of cognitive and metacognitive approaches. Yaroslavl, Yaroslavl State University named after P.G. Demidov, 2012. Pp. 35-121.

6. Kashapov M.M. Psychology of pedagogical thinking. Monograph. SPb, Aleteiia, 2000, 463 p.

7. Kashapov M.M. Psychology of professional pedagogical thinking. M., Publishing House of Institute of Psychology, Russian Academy of Sciences, 2003, 398 p.

8. Kashapov M.M. Psychology of the creative process in the conflict. Yaroslavl, Yaroslavl State University named after P.G. Demidov, 2011, 296 p.

9. Kashapov M.M. Improving professional's creative thinking. Moscow-Yaroslavl, MAPN, 2006, $313 \mathrm{p}$.

10. Kashapov M.M. Stages of professional's creative thinking. Yaroslavl, Remder, 2009, 380 p.

11. Kiseliova T.G. Social and psychological peculiarities of level characteristics of professional pedagogical thinking in the evaluation process. Thesis for Candidate of Psychological Sciences. Yaroslavl, 1999, $154 \mathrm{p}$.

12. Ogorodova T.V. Acmeological bases of pedagogical activities: tutorial. Yaroslavl, Yaroslavl State University named after P.G. Demidov, 2010, 116 p.

13. Razina, T.V. Features of reflection at different levels of pedagogical thinking. Thesis for Candidate of Psychological Sciences. Yaroslavl, 2002, 243p. 
14. Rubinstein S.L. Fundamentals of general psychology: in 2 volumes. V.1. M.: Pedagogika, $1989,488 \mathrm{p}$.

15. Shadrikov V.D. Mental human development. M., Aspect Press, 2007, 284 p.

16. Shadrikov V.D. Problems of professional activity systemogenesis. M., Nauka, 1982, 182 p.

17. Shliapnikova O.A. Personal determinants of professionalization of preschool teachers. Thesis for Candidate of Psychological Sciences. Yaroslavl, 2010, 215 p.

18. Skvortsova Iu.V. Metacognitive components of pedagogical thinking of high school teacher. Thesis for Candidate of Psychological Sciences. Yaroslavl, 2006, $201 \mathrm{p}$.

19. Tomchuk S.A. The ratio of musical and pedagogical thinking in the professional work of the music teacher. Thesis for Candidate of Psychological Sciences. Yaroslavl, 2007, 237 p.

\title{
Надситуативность как основа \\ творческого профессионального мышления
}

M.М. Кашапов

Ярославский государственный университет им. П.Г. Демидова Россия, 150057, Ярославль, проезд Матросова, 9

\begin{abstract}
Проблема диагностики и формирования творческого профессионального мышления является одной из фундаментальных проблем в педагогической психологии. Творческие способности играют важную роль в профессиональной деятельности, поэтому низкий уровень сформированности креативной компетентности не позволяет продуцировать эффективные стратегии и способы педагогической деятельности, приводит к выбору некорректных, неконструктивных способов поведения, не способствует осознанию своей деятельности и, как следствие, приводит к профессиональной стагначии педагога.

Встатьепредставленоисследование, посвященноерешениюважнойпсихолого-педагогической проблемы - вылвлению, описанию, диагностике и формированию надситуативности как основы творческого профессионального мышления. В статье обосновывается, что в педагогической деятельности надситуативный тип мышления учителя выступает ведущей, ключевой компетениией, без которой невозможно осуществление педагогического прочесса на высоком уровне.
\end{abstract}

Ключевые слова: надситуативный тип мышления, творческое профессиональное мышление, педагогическая деятельность.

Работа выполнена при финансовой поддержке РГНФ (Проект № 13-06-00589а)/

Научная специальность: 13.00.00 - педагогические науки, 19.00.00 - психологические науки. 